Article

\title{
The Use of Oral Histories to Identify Criteria for Future Scenarios of Sustainable Farming in the South Yangtze River, China
}

\author{
Pingyang Liu ${ }^{1}$, Juan M. Moreno ${ }^{1,2}$, Peiying Song ${ }^{1}$, Elona Hoover ${ }^{1,2}$ and Marie K. Harder ${ }^{2,3, *}$ \\ 1 Department of Environmental Science and Engineering, Fudan University, Shanghai 20433, China; \\ pyliu@fudan.edu.cn (P.L.); J.Moreno@brighton.ac.uk (J.M.M.); peiying_song@163.com (P.S.); \\ E.Hoover@brighton.ac.uk (E.H.) \\ 2 Values and Sustainability Group, School of Computing, Engineering and Mathematics, \\ University of Brighton, Brighton BN2 4GJ, UK \\ 3 Department of Environmental Science and Engineering, Fudan Tyndall Centre, Fudan University, \\ Shanghai 20433, China \\ * Correspondence: M.K.Harder@brighton.ac.uk; Tel.: +44-127-360-0900
}

Academic Editors: Iain Gordon and Manuel González de Molina

Received: 15 April 2016; Accepted: 23 August 2016; Published: 29 August 2016

\begin{abstract}
Agricultural practices in Jiangnan water towns have historically been identified as maintaining a balance between human activity and the local environment, but are now a significant local source of water pollution. Using a multi-methods approach, this study deduces the environmental impact of traditional practices, and the socially desired conditions for successfully reintroducing critical ones. Oral histories from 31 farmers in Tianshanzhuang village, South Yangtze River were in order to chart changes in farming practices over four historic periods, and used to estimate the nitrogen and phosphorus burdens per acre. Findings show that the use of Lan River Mud — dredged mud for fertilizer — was key in producing a positive impact, but abandoned after the 1980s. Four criteria hindering reintroduction of traditional practices were identified, and potentially useful but fragmented emerging local candidate practices are considered against these, as are recent practices in Japan. We propose that the cooperation of several stakeholders with various related government departments in China could lead to a portfolio of effective policy changes and should be studied further: to include new methods and uses of Lan River Mud; the integration of aquaculture, leisure and tourism industries with agriculture; and the production of organic produce with well-planned internet-linked sales, delivery and coordination mechanisms.
\end{abstract}

Keywords: farming practices; oral history; sustainable farming; environmental impact; environmental impact assessment

\section{Introduction}

Traditional Chinese agricultural practices have attracted increasing attention due to their historically high yields and their positive contributions to local environments, namely in terms of ecological biodiversity [1-3]. Liu et al. and Ye et al. highlight the role of holistic wide-ranging farming techniques, such as the combination of space-time and food chain considerations in cultivation patterns $[3,4]$. Other works have examined specific impacts of practices such as circular farming and dredging of river mud with regard to the accumulation of organic materials in soil, the conservation of water resources and contribution to the adjustment of air composition [5-8].

Located at the southern end of the Yangtze River Delta, the Jiangnan region is historically well known for the resource-saving and locally adapted nature of its agricultural practices. Farmers' deep understanding of soils and local water resources allowed them to achieve high yields without damaging 
the health of the land or exceeding its production capacity [9]. Equally important was the balance between practical "know-how" and the ability to incorporate new, external knowledge to inform farming practices which has been passed from generation to generation [10].

Following China's economic reform during the past 40 years, the country has experienced significant transformations in the agricultural sector, with many traditional practices being lost. Most noticeable among these changes have been the state-led intensification of agricultural production, new irrigation systems, the increasing usage of fertilizers and pesticides, as well as the decline of farm labour due to an aging population and the hollowing-out of rural areas [11-16]. The new infrastructure and inputs have led to substantial increases in national and regional crop yield since the 1980s [17]; the authors estimate regional crop yields increased from $200 \mathrm{~kg}-300 \mathrm{~kg}$ per mu without chemical fertilizers and pesticides in the Pre-Liberation period, to over $500 \mathrm{~kg}$, with a peak at $750 \mathrm{~kg}$ per mu in the Open and Reform period. However, these shifts have contributed to the rapid degradation of the Jiangnan region's ecological environment, with agriculture now being blamed as the main source of water pollution and food contamination in Shanghai [18-20]. This is of particular concern given the fact that around $90 \%$ of green-leaf vegetables in Shanghai are produced for local consumption [21]. In addition, these transformations have undermined the balance between local farmers and their use of the land, and resulted in significant changes to the structure and organisation of rural communities.

In the described context, there has been an increasing interest in organic farming and ecological agriculture, perceived in China to have the potential to provide more healthy and safe products through environmentally sustainable production methods ([22], pp. 551-553). This interest for ecological agriculture has been prompted by the growing concerns over food safety of a rising Chinese and urban-based middle class, and the interest of the Chinese government to meet international standards for organic food, especially following the opening of domestic markets to the World Trade Organization [22-25]. However, such changes in practices are piecemeal, and general solutions for agricultural production are not always easily adapted to specific production contexts, such as the South Yangtze Delta region.

Several studies have examined socio-economic and structural factors obstructing the development of more sustainable forms of farming. These include farmers' socio-economic realities vis-à-vis urbanites, and in particular high income inequalities, lack of access to technologies and methods of land cultivation, as well as unwillingness to adopt new crop varieties [15,26-28]. As Sanders explains [11,29], despite the growing demand for more green and organically grown produce from the cities, Chinese existing structural weaknesses in the agricultural sector, such as the fragmentation and frequent redistribution of landholdings, low levels of mechanization and inadequate access to capital, prevent farmers from fully engaging in more sustainable farming.

Broader structural factors resulting from Chinese land reforms have also limited the adoption of more sustainable agricultural practices. In a recent paper, Ye [30] argues that land reforms and institutional transitions in China over the last 30 years have been "urban biased", with farming and the countryside acting "as an open conduit, nourishing the cities" ([30], p. 332), thus limiting the positive impact on farmers' livelihoods. Chen and Davis examine the more specific impact of the Household Responsibility System (HRS) during the end of the 1970s and the 1980s on the agricultural sector [31]. As the authors explain, while the HRS led to an increase in the production of China's three main crops (grain, cotton and oil-bearing crops) and the extension of farmers' land use rights and decision-making power, it also resulted in an apparently endless redistribution of land. The resulting lack of security to retain land or investments reduced farmers' willingness to engage in land conservation or mechanize their practices, and led to increased fragmentation, intensification, over-exploitation and focus on short-term returns. Furthermore, in an effort to reduce the increasing speed of agricultural land loss-4.73 million hectares lost between 1978 and 1996-the Chinese government introduced further policies to maintain a "dynamic balance" of agricultural land [32]. However, this further enhanced the lack of security to retain land, with rapid urbanisation leading to displacement of cultivated land 
to other areas within a province, or another province entirely, often reclaiming land without any consideration of broader environmental impacts [Ibid].

These challenges notwithstanding, the interest in minimising the negative impacts of agricultural production in the South Yangtze Delta region is growing, towards a model that will provide environmental services for the neighbouring large urban areas rather than focusing on maximising yields. While the positive environmental effects of traditional farming practices have been studied and widely accepted from a historical perspective, the detail and function of these practices have not been sufficiently explored. There are almost no studies examining the link between specific farming practices and their potentially beneficial environmental impacts in the Jiangnan region. Two exceptions are the work of Lv et al. on environmental externalities [33] and Li and co-workers' work on the revitalization of traditional agricultural areas through community-based rural residential land consolidation and allocation practices [34]. Lv et al. argue that much of the recent works on environmental externalities has been focused on biodiversity and landscape rather than agro-systems ([35], p. 1437). Their examination of the rice-wheat farming system in Zhenjiang, Jiangsu Province provides estimates on the monetary value of both positive and negative environmental externalities in the region. They conclude that while greenhouse gas emissions and non-point source pollution have negative impacts on the environment, "crops and soil in Zhenjiang are very important carbon sinks and that agriculture in Zhenjiang shows huge positive environmental externalities" ([35], p. 1441). $\mathrm{Li}$ and co-workers' work examines endogenous institutional innovations and self-organized rural planning and decision making processes in traditional agricultural areas in Dancheng, Henan Province. The authors conclude that the promotion of these factors is crucial for a successful and balanced revitalization of hollowed villages and "could provide integrated platforms for developing modern agriculture, stabilizing grain production and promoting new countryside construction" ([29], p. 196).

Further, while there has been much work on the structural and socio-economic issues limiting the uptake of more sustainable agricultural practices, there has been little work examining how current agricultural practices could benefit from adopting or adapting local traditional practices. Liu's recent work on knowledge cultures [9] provides some insight into this question, arguing that it is not so much a question of "failure" to pass on agricultural knowledge as one of "unwillingness" to do so as local farmers are replaced with professional workers, and they can find higher income work elsewhere.

Three important questions stand out for our consideration: What traditional practices had the most beneficial environmental impacts? Could such practices be re-introduced? What conditions are necessary in order to make these changes happen?

In order to address these questions, we examine the case of Tianshanzhuang village, an agricultural town in the South Yangtze River delta, using an oral history approach to generate data for analysing the environmental impact of farming practices in recent Chinese history over 100 years, from the Pre-Liberation period (pre-1949) to the Open and Reform period (post-1980s). This allows us, first, to identify detailed farming practices that may be the most environmentally beneficial to re-introduce in the region. Second, we use the data generated from the oral histories to identify specific, locally relevant criteria that are needed in order to successfully re-introduce or substitute for such practices. Third, we consider recent changes in practices in Japan in light of these criteria, as well as emerging fragments of practices in China. We finish the paper with some recommendations for further areas of work towards viable environmental programmes and policy.

\section{Methods}

\subsection{Study Area}

Tianshanzhuang village forms part of Jinze Township, a traditional water town $60 \mathrm{~km}$ from the urban central area of Shanghai, in the upper reaches of the Huangpu River, South of the Yangtze River (Figure 1). The village covers an area of $4.35 \mathrm{~km}^{2}$, of which $1.5 \mathrm{~km}^{2}$ are of arable land, including $0.8 \mathrm{~km}^{2}$ of grain fields, $0.01 \mathrm{~km}^{2}$ of perennial vegetables, and $0.7 \mathrm{~km}^{2}$ are fish ponds. 
The main crop cultivated is rice, and other grains include canola and wheat. It is a water town village, with 1314 local inhabitants in 505 households, and 12 village groups. There are also 341 non-locals living in the village.

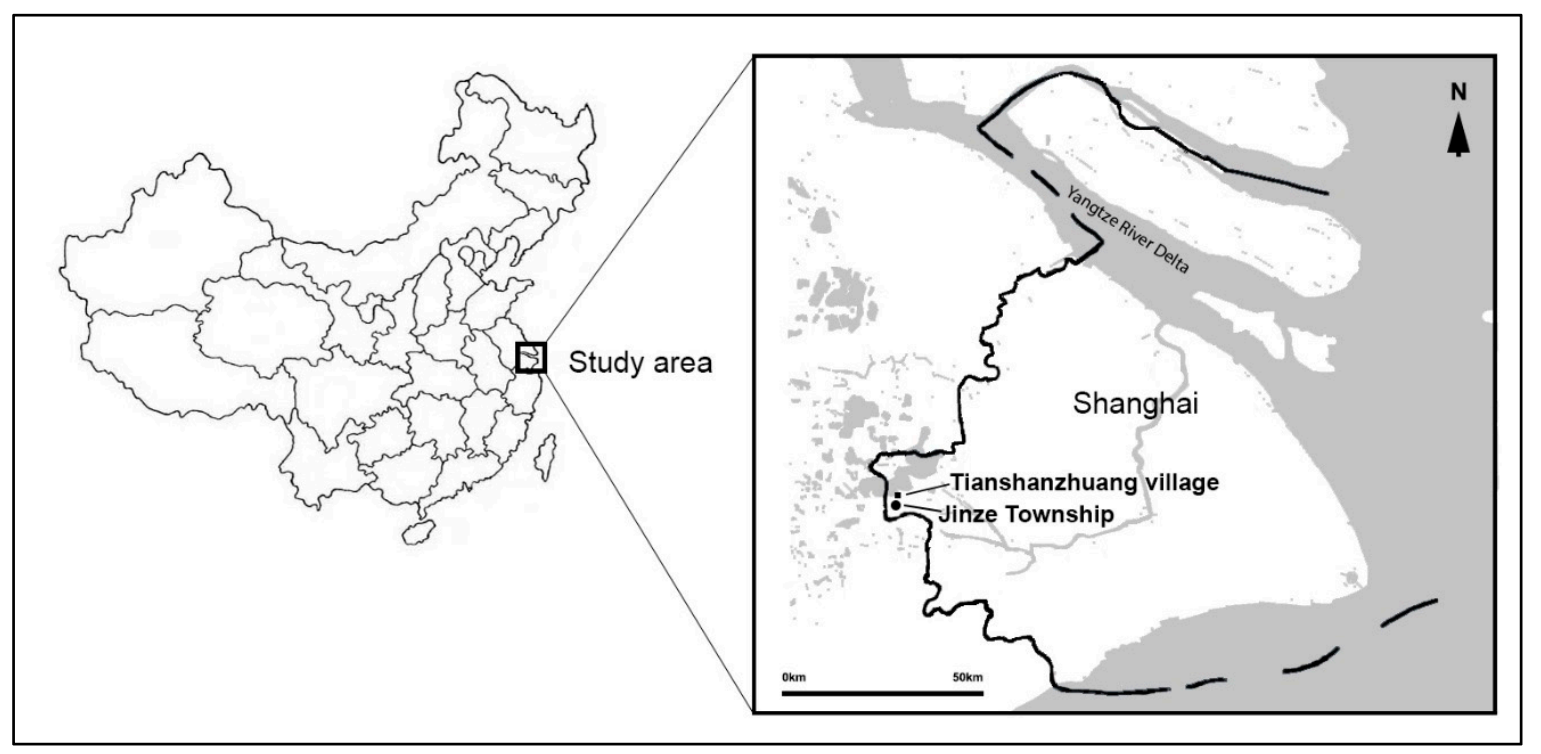

Figure 1. Location of Tianshanzhuang village.

Tianshanzhuang village was selected for this study given its long history of traditional Jiangnan-style farming and its current fertilizer driven water pollution problems arising from the intensive agriculture practices introduced over the past four decades. It is relatively isolated from the urban centre, and has been included in the Drinking Water Source Zone of Shanghai since 1990s, which make possible that agriculture remains as the main industry in the village. Thus it provides a rare opportunity to study the changes of farming over the past 100 years, covering the traditional type (pre Liberation), the collective type (about 1950-1979), and the modern type (after 1980).

\subsection{Methodology}

Oral history is a well-established methodological approach for historians and social scientists to collect data about people's lives, providing both contextual and meaningful information as well as descriptions about the past [35]. The use of oral history in agriculture as a methodological tool for data generation has also received substantial attention [36-40]. It is an important and practical research tool as it first exposes individual life experiences and voices that are often not heard or that documentary history fails to explain. Second, it helps understand farmers' motivations, sentiments and meanings to changes in farming practices and larger structural forces affecting them $[35,36]$.

In China, the use of oral histories is not only practical but also necessary due to the significant lack of socio-economic data and written historical records at the village level. While statistical information on population, income and household data has been widely collected through surveys [41], the history, stories, and lifestyles in villages have been passed from generation to generation mainly orally. However, in recent years, and driven mainly by the impact of industrialization and rapid urbanization, many farmers, especially the young, give up agriculture and migrate to the cities in search for jobs. Consequently, the current elderly farmers-the only population who still preserves the memory of traditional farming practices-seem unable to pass on their knowledge [31].

In this context, Tianshanzhuang's predominantly elderly farming population offers a unique opportunity to collect contextually relevant information about historical farming practices and knowledge that would otherwise be lost. This study uses oral histories from the Tianshanzhuang village to: (1) examine changes in agriculture production across three historical periods; (2) elicit 
information useful to estimate the broad environmental impact of different practices; and (3) identify basic criteria indicated by interviewees as required to reintroduce key practices or their equivalents for successfully integrating traditional farming practices into future agricultural policies.

\subsection{Oral Histories Data Collection and Analysis}

Oral histories were documented from a population sample of 31 elderly farmers in the village belonging to three age groups: over 80 years old, between 70 and 79, and between 50 and 69 (see Table 1). These were chosen in order to identify changes in farming practices across three main periods of Chinese recent history: Pre-Liberation period (1949), Collective Economy period (1950s-1970s), and Open and Reform period (since 1980s onwards). Interviewees for the eldest group included all the farmers, excluding those living outside the village, and incapable of communication. For the second age group, interviews were facilitated by the Head of the Old People's Association of the village, and members of the last group were nominated by the Vice-Head of the Village Committee.

Table 1. Participating elderly farmers by age, gender and main historical period.

\begin{tabular}{cccc}
\hline Historical Periods & $\begin{array}{c}\text { Pre-Liberation } \\
(\mathbf{- 1 9 4 9 )}\end{array}$ & $\begin{array}{c}\text { Collective Economy } \\
\mathbf{( 1 9 5 0 - 1 9 7 0 s )}\end{array}$ & $\begin{array}{c}\text { Open and Reform } \\
\text { (1980s-) }\end{array}$ \\
\hline Age & $\geq 80$ & $60-79$ & $50-69$ \\
Male & 8 & 7 & 5 \\
Female & 7 & 3 & 1 \\
Total & $\mathbf{1 5}$ & $\mathbf{1 0}$ & $\mathbf{6}$ \\
\hline \multicolumn{2}{c}{ Source from authors. }
\end{tabular}

Semi-structured interviews were conducted with groups of two to three researchers, including one local researcher who knew the farmers' local Shanghainese dialect. Interviews took place between late March and early April 2011. Each interview lasted around two hours and were only recorded with the consent of the farmers. Interview summaries and field reports were written up on the same evening by the interviewers and later translated into English. Farmers are only referred to by gender and age to protect their privacy. A complementary field visit took place in June that same year to clarify the ambiguity of the records and look for more details of some stories.

For the two older age groups, interviews focused on three broad topics: how they farmed and how this has changed; what fertilizer they used and in what quantities; and what they perceived to be the quality of the water. The youngest age group were asked about their current farming practices; how major regional economic developments have impacted in their methods of production; and what changes they have seen in the village.

The data generated from the oral histories were examined in three stages. First, the authors carried out an analysis of the histories to identify specific traditional farming practices that were likely to have significant environmental impacts—-positive and negative ones. Second, specific oral history data were converted into quantitative estimates of the relevant environmental impacts of agriculture production in the three different historical periods: these were found to be dominated by changes in fertilizers use and the consequent effect on water pollution. In order to better estimate the environmental impacts of fertilizers on water sources across each time period, data generated from the oral histories were related to average amounts of fertilizer used per mu (where $15 \mathrm{mu}=1$ hectare) of farmland. Third, the authors developed, from the data, a list of criteria for the successful reintroduction of traditional farming practices with the most significant environmental benefits.

\subsection{Environmental Impact Assessment of Farming Practices}

Based on the rich information within the oral histories, the authors calculated key environmental impacts of the farming practices. A typical household with three members living on $5 \mathrm{mu}$ of farmland was set up as the basic scenario for analysis. Examples of the kind of information contained in the 
oral histories is given below, which gives the reader a feel for its authenticity and the required steps to calculate unit equivalents:

"The river mud was always used as the primary fertilizer. Normally there had to be 10 boatloads of wet river mud [approximately 3 tonnes] per mu ... there was an old saying: after carrying 18 loads of river mud, you would never prefer smoking to a meal."(Male, 81)

"The most common types of chemical fertilizer at that time were Tan'an $\left[\mathrm{NH}_{4} \mathrm{HCO}_{3}\right]$ and An'Shui $\left[\mathrm{NH}_{3} \mathrm{H}_{2} \mathrm{O}\right]$. The quota per mu was $400 \mathrm{Jin}(200 \mathrm{~kg})$ Tan'an. The price was only 0.1 yuan per Jin (very cheap ... After several years, the procedure of purchase was simplified and you could buy as much as you wanted."(Male, 68)

"Before Liberation, few households raised pigs-because of insufficient food: less than 30 out of total 300 households. It was not until the time of the Production Teams that every household began to raise pigs. There was also a collective pig farm in the village."(Male, 81)

Life Cycle Assessment (LCA) is a useful methodology for the study and evaluation of the environmental impacts of farming practices. However, due to the limitations of lifecycle environmental assessment of agriculture in this context, such as poor data availability [42], unclear boundaries [43,44] and complicated connections with the nature and the society, the authors instead carried out an environmental impact assessment across the past 100 years, for each of the Chinese historical periods studied, using metrics widely used in LCA rather than an actual LCA [45]. The analysis was structured using the farming of paddy rice- the most representative and widely cultivated crop in the Yangtze River Delta—as the research object. According to the data available from oral histories, and the fact that eutrophication has been one of the main local environmental challenges since 1980s [46], we focused on the Eutrophication Potential (EP) and the Acidification Potential (AP) assessment, which were mainly caused by the changing of fertilizer use across the past 100 years (Figure 2). Even though the Global Warming Potential (GWP) of farming is attracting worldwide attention and is of interest, the oral histories in this work could not generate sufficient relevant data, especially for the raw materials input and transportation. Thus, GWP considerations were excluded. Land area (mu) was used as the functional unit instead of the weight unit (tonne), as land area unit works better for non-market products and service according to Payraudeau and van der Werf [43].

\begin{tabular}{|c|c|c|}
\hline $\begin{array}{l}\text { Input per mu of rice } \\
\text { ·fossil fuels } \\
\text { ·chemical fertilizer }\end{array}$ & $\begin{array}{l}\text { Raw material } \\
\text { Electricity, fossil } \\
\text { fuels minerals etc. }\end{array}$ & $\begin{array}{l}\text { Output per mu } \\
\text { (Discharge into air, water and } \\
\text { soil) }\end{array}$ \\
\hline $\begin{array}{l}\text { (urea, ammonium } \\
\text { bicarbonate, SSP etc.) } \\
\text { ·organic fertilizer }\end{array}$ & $\begin{array}{l}\text { Farming inputs } \\
\text { Fertilizers }\end{array}$ & $\begin{array}{l}\text {-greenhouse gas: } \mathrm{N}_{2} \mathrm{O} \\
\text { 'eutrophication substances: } \\
\mathrm{NO}_{3}^{-}\end{array}$ \\
\hline $\begin{array}{l}\text { (river mud, manure, } \\
\text { plant fertilizer etc.) }\end{array}$ & & $\begin{array}{l}\text {-acid substances } \mathrm{NH}_{3}, \mathrm{NOx} \\
\text { ·toxic substances }\end{array}$ \\
\hline $\begin{array}{l}\text {.pesticide } \\
\text {.land }\end{array}$ & $\begin{array}{l}\text { Soil characteristics } \\
\text { Transportation } \\
\text { Fossil fuels }\end{array}$ & $\begin{array}{l}\text { 'heavy metals } \\
\text { other pollutants }\end{array}$ \\
\hline
\end{tabular}

Figure 2. The framework for water environmental assessment used in this study, overlaid on that used by Brentrup et al. [32].

The first step was to understand the types and the amount of fertilizers used in different stages. Those fertilizers which were widely mentioned in the oral histories were considered, with calculations 
made for those mentioned repeatedly and cross-referenced in multiple interviews: the less common ones or references to apparently small amounts were not considered further. In particular, human and animal faeces (including pig and chicken manures), clovers, river mud and chemical fertilizers are included, while ashes, bean pies, etc. are excluded (see Table 2).

Table 2. Types and amounts of fertilizer used in Tianshanzhuang village during different historical periods, with deduced nitrogen and phosphorus burdens in $\mathrm{kg} / \mathrm{mu}$.

\begin{tabular}{|c|c|c|c|c|}
\hline Historical Periods & Fertilizer & $\begin{array}{c}\text { Amount } \\
\text { per mu/kg }\end{array}$ & $\begin{array}{l}\text { Total N Input } \\
\text { per } \mathrm{mu} / \mathrm{kg}\end{array}$ & $\begin{array}{l}\text { Total P Input } \\
\text { per } \mathrm{mu} / \mathrm{kg}\end{array}$ \\
\hline \multirow{5}{*}{$\begin{array}{c}\text { B.L. } \\
\text { (Before Liberation, } \\
-1949)\end{array}$} & chicken manure & 43.80 & 1.29 & 0.71 \\
\hline & human waste & 40.15 & 1.23 & 0.21 \\
\hline & clover & 360 & 1.73 & 0.40 \\
\hline & river mud (dry) $\left({ }^{*}\right)$ & 4200 & 2.81 & 2.10 \\
\hline & Total & & 7.06 & 3.41 \\
\hline \multirow{6}{*}{$\begin{array}{c}\text { C.E1 } \\
\text { (Collective Economy, } \\
\text { early stage, 1950-1958) }\end{array}$} & chicken manure & 109.50 & 3.23 & 1.76 \\
\hline & pig manure & 47.50 & 2.79 & 1.49 \\
\hline & human waste & 40.15 & 1.23 & 0.21 \\
\hline & clover & 1800 & 8.64 & 1.98 \\
\hline & river mud (dry) & 1,2600 & 8.44 & 6.30 \\
\hline & Total & & 21.10 & 9.98 \\
\hline \multirow{9}{*}{$\begin{array}{c}\text { C.E2 } \\
\text { (Collective Economy, } \\
\text { late stage, 1958-1983) }\end{array}$} & chicken manure & 109.50 & 3.23 & 1.76 \\
\hline & pig manure & 47.50 & 2.79 & 1.49 \\
\hline & human waste & 40.15 & 1.23 & 0.21 \\
\hline & clover & 1800 & 8.64 & 1.98 \\
\hline & river mud (dry) & 6300 & 4.22 & 3.15 \\
\hline & ammonia & 25 & 3.75 & 0.00 \\
\hline & ammonium bicarbonate & 25 & 3.98 & 0.00 \\
\hline & calcium superphosphate & 25 & 0.00 & 4.11 \\
\hline & Total & & 27.85 & 12.71 \\
\hline \multirow{6}{*}{$\begin{array}{c}\text { O.P1 } \\
\text { (Open and Reform, } \\
\text { HRS, 1983-2000) }\end{array}$} & chicken manure & 32.85 & 0.97 & 0.53 \\
\hline & human waste & 3.01 & 0.09 & 0.02 \\
\hline & urea & 20.00 & 9.20 & \\
\hline & ammonium bicarbonate & 50.00 & 7.97 & 0.00 \\
\hline & calcium superphosphate & 50.00 & 0.00 & 4.11 \\
\hline & Total & & 18.23 & 4.66 \\
\hline \multirow{3}{*}{$\begin{array}{c}\text { O.P2 } \\
\text { (Open and Reform, } \\
\text { Land Transfer, 2000-) }\end{array}$} & urea & 32.50 & 14.95 & 0.00 \\
\hline & pound fertilizer & 55.00 & 12.65 & 4.13 \\
\hline & Total & & 27.60 & 4.13 \\
\hline
\end{tabular}

Source: The data of fertilizer application (amount per mu) were calculated by the Authors from the oral histories; $\left(^{*}\right)$ The amount for dry Lan River Mud application is based on the following estimates: 1 boatload $=20$ dan (local units), where 1 dan $=60 \mathrm{~kg}$; water content of river mud 65\% (see Table 3).

Second, we used local applied technical parameters to translate the fertilizers to total N and P: the coefficients of total $\mathrm{N}$ and $\mathrm{P}$ of human and animal faeces were from Administration Instructions of the instruction of the Ministry of Environmental Protection [47]; those of red covers were from local studies [48], and those of river mud were mainly based on oral histories of local elderly farmers' experiences and historical literature [49].

Third, the utilizations and leakages of total $\mathrm{N}$ and $\mathrm{P}$ were estimated for different farming practices. Technical parameters were mainly from oral histories and existing literatures, as summarised in Table 3.

Finally, we calculated the Acidification Potentials and Eutrophication Potentials for different farming practices. Characterization and standardization were carried out based on equivalent coefficients from existing references (Tables 4 and 5). The potential result of environmental impact can then be calculated according to:

$$
\mathrm{EP}(x)=\sum \mathrm{EP} x(y)=\sum \mathrm{E} y \times \mathrm{CF} x, y
$$


where E P $(x)$ is the potential environmental impact $x$, which are the Acidification Potential and Eutrophication Potential; E P $x(y)$ is the environmental impact of substance $y$; E $y$ is the emission of substance $y$ per function unit; and CF $x, y$ is the equivalent coefficient factor of substance $y$ in potential environmental impact $x$.

Table 3. List of technical parameters about $\mathrm{N}$ and $\mathrm{P}$, developed from local knowledge and published data.

\begin{tabular}{|c|c|}
\hline Contents & Technical Parameters \\
\hline Water content of river mud & $65 \%(a)$ \\
\hline $\mathrm{N}$ and $\mathrm{P}$ contents of river mud & $6.7 \%(\mathrm{~N}), 5 \%(\mathrm{P})(\mathrm{b})$ \\
\hline $\mathrm{N}$ and $\mathrm{P}$ contents of other fertilizers & $\begin{array}{l}\text { human waste: } 3.06 \%(\mathrm{~N}), 0.52 \%(\mathrm{P})(\mathrm{c}) \\
\text { pig manure: } 5.88 \%(\mathrm{~N}), 3.14 \%(\mathrm{P})(\mathrm{c}) \\
\text { chicken manure: } 9.48 \%(\mathrm{~N}), 5.37 \%(\mathrm{P})(\mathrm{c})\end{array}$ \\
\hline $\mathrm{N}$ and $\mathrm{P}$ contents of Clover & $0.48 \%(\mathrm{~N}), 0.11(\mathrm{P})(\mathrm{d})$ \\
\hline Volatilization of $\mathrm{NH}_{3}-\mathrm{N}$ & $28 \%$ of the total $\mathrm{N}$ input $(\mathrm{e})$ \\
\hline $\begin{array}{c}\text { Rate of } \mathrm{NO}_{3}-\mathrm{N} \text { loss due to leaching and run-off } \\
\text { during the cropping season }\end{array}$ & $6 \%$ of the total $N$ input $(f)$ \\
\hline Volatilization of $\mathrm{NO}_{X}-\mathrm{N}$ & $10 \%$ of the volatilization of $\mathrm{N}_{2} \mathrm{O}-\mathrm{N}(\mathrm{g})$ \\
\hline Loss of $\mathrm{P}$ by run-off & $0.86 \%$ of fertilizer input and $1.44 \%$ of manure input $(\mathrm{h})$ \\
\hline General loss of $\mathrm{N}$ and $\mathrm{P}$ in different historical periods & $\begin{array}{l}\text { Pre-Liberation to Collective Economy periods (dominated by } \\
\text { organic fertilizers): } 8 \% \text { for N, and } 0 \% \text { for } \mathrm{P} \\
\text { Open and Reform period (HRS and Land Transfer stages, } \\
\text { dominated by chemical fertilizers): } 30 \% \text { for } \mathrm{N} \text { and } 12 \% \text { for } \mathrm{P} \\
\left(\text { (i) }\left({ }^{*}\right)\right.\end{array}$ \\
\hline
\end{tabular}

Sources: (a) Authors calculation based on data from oral histories. It was estimated by local farmers that 200 dan of wet river mud produced 60-70 dan of dry river mud;(b) [49]; (c) [47]; (d) [48]; (e) [50-52]; (f) [53]; (g) [45]; (h) [8]; (i) [54]; $\left(^{*}\right)$ Notes: The movement of $\mathrm{N}$ and $\mathrm{P}$ is complex and determined by various factors such as the timing of application and corresponding weather conditions see [55]. In addition, the application of chemical, organic or mixed fertilizers in rice paddy cultivation in Southeastern China can lead to changes in soil microbial diversity, which in turn influences the use efficiency of $\mathrm{N}$ [56]. However, there are a lack of specific data available on $\mathrm{N}$ and $\mathrm{P}$ loss rates for the agricultural system studied; therefore, the authors estimated rough rates with the help of local experts. For the Pre-Liberation to Collective Economy periods, the estimation was based on local studies of the optimal zone of fertilizer input for rice cultivation; before the Open and Reform Period, the soil was generally $\mathrm{N}$ and $\mathrm{P}$ deficient, thus the loss of $\mathrm{N}$ and $\mathrm{P}$ were mainly due to runoff, which was estimated at $10 \%$ for $\mathrm{N}$, and $1 \%$ for $\mathrm{P}$ [57]. The utilization rate of human and animal faeces were estimated at $70 \%$ [58], and the rest was treated as losses to the environment. Thus, an overall loss rate of $8 \%$ was set for $\mathrm{N}$, and $0 \%$ for $\mathrm{P}$. For the Open and Reform period, the increased use of chemical fertilizers starting in the 1990s led to a rapid increase in the loss of N and $\mathrm{P}$, due, for instance, to increased external input, soil depth and irrigation systems [55]. Prior to 2000, organic fertilizers such as animal manures were soon no longer used and discharged directly into the water; thus respective $\mathrm{N}$ and $\mathrm{P}$ contents were regarded as losses into the environment. After 2000, pig raising was banned by the government, and human waste was collected and treated: for this reason, only the loss of chemical fertilizers was considered in the last period. Overall, the loss of $\mathrm{N}$ and $\mathrm{P}$ were estimated to be $30 \%$ and $12 \%$, respectively.

Table 4. List of equivalent coefficients of Eutrophication.

\begin{tabular}{ccc}
\hline Environmental Impact & Substance & Equivalent Coefficient \\
\hline \multirow{3}{*}{ Environment acidification } & $\mathrm{SO}_{2}$ & 1 \\
& $\mathrm{NH}_{3}$ & 1.88 \\
& $\mathrm{NOx}$ & 0.7 \\
\hline \multirow{5}{*}{ Eutrophication } & $\mathrm{PO}^{4-}$ & 1 \\
& $\mathrm{TP}$ & 3.06 \\
& $\mathrm{NO}_{x}$ & 0.13 \\
& $\mathrm{NO}^{3-}$ & 0.42 \\
& $\mathrm{NH}_{3}$ & 0.33 \\
\hline
\end{tabular}

Source: [46-48]. 
Table 5. The standard values and weightings of environmental impact index elements.

\begin{tabular}{ccc}
\hline Environmental Impact & Unit & Standard Value/kg per Person $\cdot \mathbf{a}-\mathbf{1}$ \\
\hline Environment acidification & $\mathrm{kgSO}_{2}$-eq & $52.26(\mathrm{a})$ \\
Eutrophication & $\mathrm{kgPO}_{4}{ }^{3-}$-eq & $1.88(\mathrm{~b})$ \\
\hline
\end{tabular}

Source: (a) [59]; (b) [60]; The weight was decided by Delphi method; as we are not doing a full LCA, thus the total weight does not add up to 1 .

The standardization was derived by:

$$
\mathrm{EIx}=\mathrm{EPx} / \mathrm{E}_{\mathrm{F}(2000)}
$$

where E Ix is the Relevant Environmental Impact Composite Index, $\mathrm{E}_{\mathrm{F}(2000)}$ is the global environmental impact potential per capita of 2000.

\section{Results}

\subsection{Changing of Farming Practices and Their Respective Environmental Impacts}

The oral histories indicated that, over the past 100 years, the farming practices of the Tianshanzhuang village changed rapidly, which we describe here briefly for context. Villagers commonly named four periods. In the years preceding the Liberation, pre-1950, and during the first stage of the Collective Economy, traditional Jiangnan agriculture was characterised by strong social connections based on the traditional family system; labour was intense and meticulous, and farmers from different households shared tools and cooperated in communal areas. During the late stage of the Collective Economy period, 1958-1983, agriculture production was reorganised with the introduction of Production Teams and new machinery. While agriculture became more efficient and farmers' opportunities for non-farm work increased, their livelihoods and the labour conditions of most households did not necessarily improve. Furthermore, farmers lost their autonomy and as farming became more mechanized, the demand for manual labour decreased. The last three decades, following the Open and Reform period in the early 1980s was marked by the introduction of the Household Responsibility System (HRS), which sought to increase private productivity in the rural areas, and led to a massive hollowing out of the workforce to factories and other jobs in the cities. This in turn resulted in a complete shift from traditional small-scale farming to large-scale and intensive agriculture production.

The analysis from the oral histories provided information of changes in the type of fertilizers used in different historical periods, and their environmental impact on local water resources. Table 2 provides a summary of the typical fertilizers described as being utilized for each historical period, and converted by the researchers into equivalent measures of nitrogen $(\mathrm{N})$ and phosphorus $(\mathrm{P})$ per kilogramme per mu of cultivated land. From the early stage of the Collective Economy period there was a serious shortage of fertilizers; farmers tried to maximize every resource at hand to enhance fertility and increase yields. They made use of human and animal faeces, red clover, ashes, and, most importantly, Lan River Mud, as base fertilizers.

"We all had ash sheds, where we accumulated the ashes from straw burning and other things. It was used as good fertilizer. My mother used to sell this kind of ashes, usually 2-3 cents per dustpan at that time. Those who raised pigs would pour it into the pigsty ground [in order to accumulate pig slurry]." (Male, 87)

"... we had to look for all kinds of fertilizers. We cut and collected grass, got river mud from rivers, and then mixed them together. When there was a strong, stinking smell, the grass was completely rotten and ready for application." (Female, 89)

At the end of the Collective Economy, chemical fertilizers start to become more available. Even though the initial products had a pungent odour, it was widely accepted as good substitute 
for river mud and the other types of fertilizers, because it had a better output with much less labour. Following the Open and Reform period, the price of chemical fertilizers dropped dramatically and became more easily accessible because of technological advances and government subsidies. Farmers completely gave up the use of Lan River Mud, and chemical fertilizers became the main source of fertilizer ever since.

Based on the data from oral history studies, we estimated the relevant local environmental impacts of farming: Eutrophication Potential and Acidification Potential (Table 6). The results show a significant increase in both the Acidification Potential and the Eutrophication Potential throughout the five historical periods. This is also consistent with the observations of some of the elders who used to depend on the river water:

“... the water was always clear. So it didn't require clearing frequently, about once in tens of years [once every ten or twenty years]. It is now completely different. No one fetches river mud and water grass for fertilizer, and the water quality is bad. It requires clearing the bottom every year but we don't do it."(Male 81)

"... the river was also our drinking water source... We used to drink the river water directly. First we fetched water into a big tank, and put some Minfan [alum], and it was ready for drink. We also washed rice and vegetables in the river."(Female 89)

Table 6. Impact indices of fertilizer use deduced for each historical period from oral histories.

\begin{tabular}{cccccc}
\hline \multirow{2}{*}{ Environmental Impacts } & Liberation & \multicolumn{2}{c}{ Collective Economy } & \multicolumn{2}{c}{ Open and Reform } \\
\cline { 3 - 6 } & Early Stage & Late Stage & HRS & Land Transfer \\
\hline $\begin{array}{c}\text { Acidification Potential } \\
\left(\mathrm{kg} \mathrm{SO}_{2} \text {-eq) }\right.\end{array}$ & 0.0080 & 0.0282 & 0.0329 & 0.0320 & 0.0242 \\
\hline $\begin{array}{c}\text { Eutrophication Potential } \\
\left(\mathrm{kg} \mathrm{PO}^{3-} \text {-eq) }\right.\end{array}$ & -0.3373 & -0.9354 & -0.1848 & 0.1758 & 0.0324 \\
\hline
\end{tabular}

Source: Authors.

To assist in the identification of the specific practices associated with this problem, the data in Table 2 were reorganised as in Figures 3 and 4 below. This revealed the significant contribution that Lan River Mud had made towards environmental health for the area, and the significant harm made by the increasing chemical fertilisers. These two practices thus became the focus of our further considerations: could Lan River Mud be re-introduced, or its lack of use mitigated in some way, and what were the social barriers to that happening?

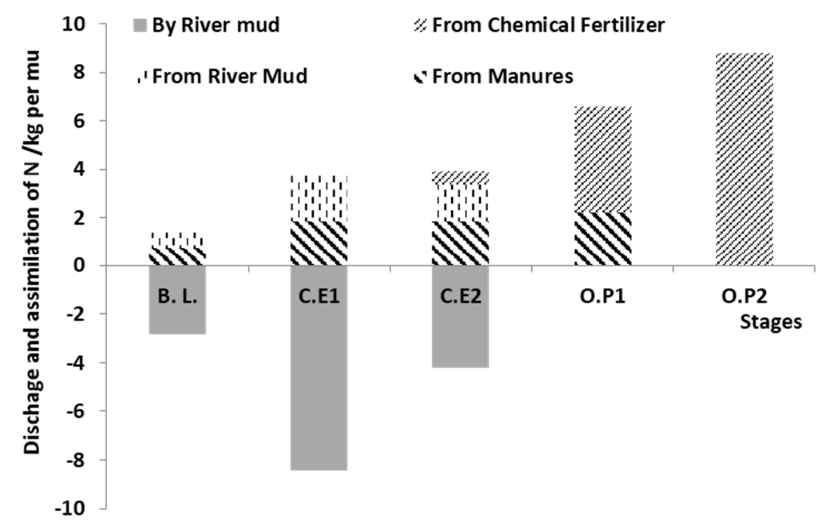

Figure 3. The shifting impact of Lan River Mud and other fertilizers on the discharge of N. Notes: B.L. (Before Liberation, pre-1949), C.E1 (Collective Economy period, early stage, 1949-1958), C.E2 (Collective Economy period, late stage 1958-1983), O.P1 (Open and Reform, Household Responsibility System period, 1983-2000), and O.P2 (Open and Reform, Land Transfer period, post-2000). 


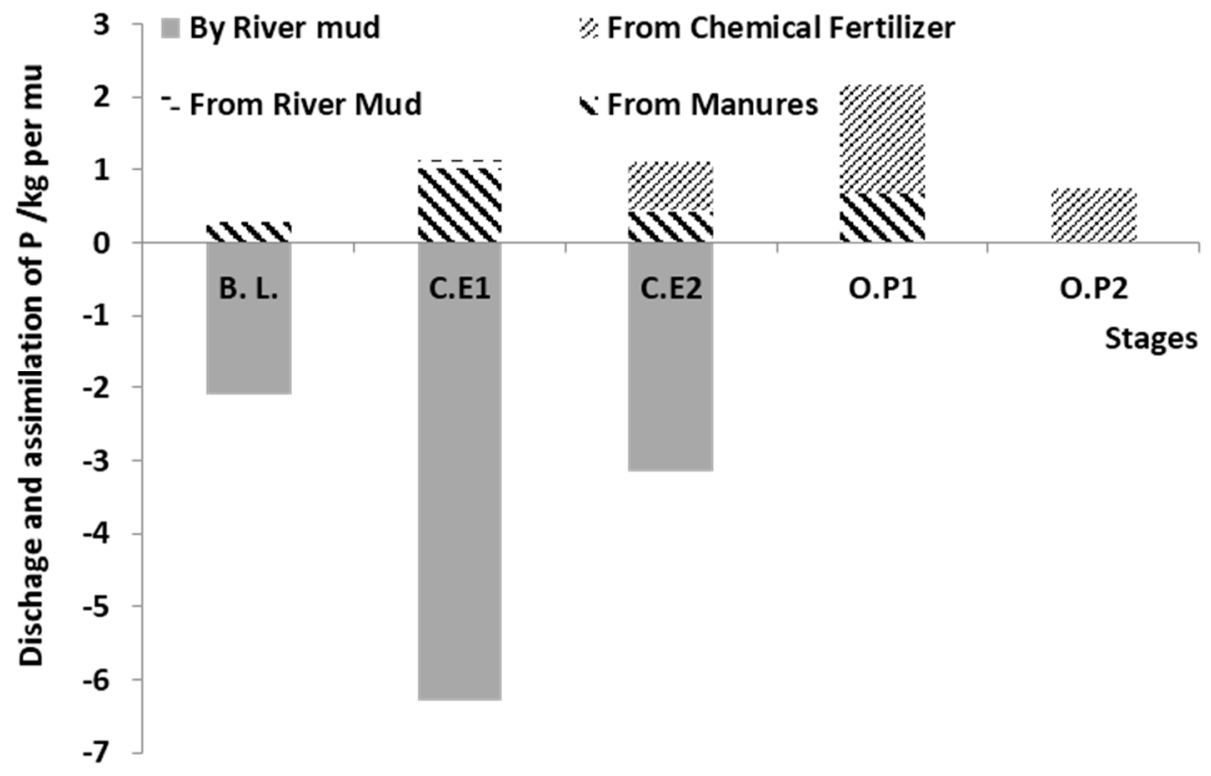

Figure 4. The shifting impact of Lan River Mud and other fertilizers on the discharge of P. Notes: B.L. (Before Liberation, pre-1949), C.E1 (Collective Economy period, early stage, 1949-1958), C.E2 (Collective Economy period, late stage 1958-1983), O.P1 (Open and Reform, Household Responsibility System period, 1983-2000), and O.P2 (Open and Reform, Land Transfer period, post-2000).

\subsection{The Importance of Lan River Mud and the Reasons for Its Replacement}

The socio-economic importance of the dredging of river mud in the South Yangtze River Delta region is broadly researched and established in academic literature [7,61-64]. In addition to being an abundant source of locally available soil fertilizer, the extraction of river mud helped reduce the silting of canals, improve the quality of water resources through the extraction of metals and other sediments from the floor bed, and restored the ecological environment of lakes, ponds and rivers.

According to the analysis, and the assumptions about $\mathrm{N}$ and $\mathrm{P}$ assimilation and loss described in the Methods, fertilizer use in the O.P and L.T stages are more likely to result in N and P runoff to nearby waterbodies. Figures 3 and 4 below show this relationship: when Lan River Mud was the main source of fertilizer, the assimilation of $\mathrm{N}$ and $\mathrm{P}$ elements (represented by the negative values in the graphic) was considerable, thus positively contributing to reduce the fertilizer-driven water pollution. Following the Open and Reform Period, the assimilation effect disappeared as the practice of Lan River Mud stopped and chemical fertilizer use increased: the loss of $\mathrm{N}$ and $\mathrm{P}$ into nearby water environment increased dramatically. While the likely impact of the increased use of chemical fertilizers on the increase in $\mathrm{N}$ and $\mathrm{P}$ discharges is consistent with the large body of work on fertilizer use and eutrophication [65,66], including recent local studies [67], the specific role of Lan River Mud in reducing $\mathrm{N}$ and $\mathrm{P}$ content in the water bodies, thus minimising risks of eutrophication, has not previously been identified.

In the nutrients cycle, Lan River Mud extraction was the only practice to close the cycle: i.e., taking $\mathrm{N}$ and $\mathrm{P}$ from the water environment, and using it for crops. Leakage of $\mathrm{N}$ and $\mathrm{P}$ elements prevailed during the Liberation and Collective Economy periods, one of the main reasons for water eutrophication, but Lan River Mud can be regarded as the key factor reducing the negative impact of farming on the local water environment at that time. Farmers' annual extraction of river mud, motivated to increase their rice output, was an effective way to reduce the risks of eutrophication of the rivers and lakes.

Before the Open and Reform Period, the most important job for the farmers was preparing as much fertilizer as possible, and the river mud was the only abundant natural resource available. People started boating as early as 3:00 a.m.-4:00 a.m. in the cold of winter mornings, and sometimes 
had to travel by ship tens of miles to get more. It was estimated that the average usage of river mud per mu was about 10 boats at the Pre-Liberation Period, while during the early stage of the Collective Economy period this peaked at 30 boats, and reduced to 15 boats in the late stage. Many rural communities even applied the practice to their village river, by organizing heavy labour work for digging river mud out for composting every winter during the farm break. It has even been regarded as the main reason for the Jiangnan watertown agriculture civilization to sustain a rural population with one of the highest densities and flourishing economic activities in the region.

As explained in the previous section, however, the use of Lan River Mud was the outcome of scarce resources available for agriculture production. People had been doing intensive farming on a small scale for thousands of years, and made use of all sorts of organic fertilizers, including human and animal faeces, to increase their yields.

Despite its key role in the extraction of nutrients and sediments for farming and the cleaning of local water sources, the fetching, drying, transporting and applying of the river mud to the farm soil was a long process and involved very intensive labour. There would usually be between 3 and 4 strong workers on a boat to dig out the river mud, and it took them almost the whole farm break period to get fairly enough fertilizers for the land. Activities began in winter, often during the Chinese Spring Festival, about three months before planting the rice. Once the river mud had been collected, farmers would lay it down and leave it to dry for 15 to 30 days to reduce its weight, and then transport it to the farm [9]. Even then, however, the weight of the river mud made transportation to the farms an arduous task:

“... the most labour consuming job was Lan River Mud and loading to the land. It was so energy exhausting that only strong men could bear it. We often got our shoulders scraped. It was about 10 turns of carrying and loading, one for 20 Dan."(Male, 87)

Farmers combined Lan River Mud with human and animal faeces as fertilisers. Two villagers describe the hard and unpleasant nature of the work:

"... at that time, the pig manure was poured into the paddy fields. We cleared the pigsty and washed the manures into the manure pit, and then carried buckets of the mixture on shoulder to the boat, shipped it to the paddy fields, and poured it into the farmland. ...the pig raising was very smelly, especially when it was hot, the stink of pig manures really unbearable."(Male, 68)

"... We used to ship the pig manures to the farmland...if there were pig manures left, we would give it to others. It was very smelly, especially in summer, and there were many mosquitoes and flies...However, compared with Lan River Mud, the latter was more laborious." (Male, 60+)

In this context, the abandonment of the Lan River Mud practice, along with the extensive utilization of other organic fertilizers such as human manure and animal faeces, became predictable as cheaper, less dirty and more easily applicable chemical fertilizers became more available during the Open and Reform years:

“... It was obvious that the output was increasing after using chemical fertilizers, and Lan River Mud was really tough. Nobody continued [after the chemical fertilizer was widely available]." (Male, 75)

The replacement of these traditional farming practices coincided with socio-economic structural changes happening at the end of the Collective Economy period. Before Liberation, the shadow price of farm labour was almost inexistent; labour was considered "free", more a way of life than a job, and the best, most honoured farmers were those with most knowledge of farming practices [9]:

"There was little difference between the past and nowadays that the rich are always of prestige. However, in the past, those with more farming experience and knowledge tended to be of more prestige." (Male, 81 ) 
During the Collective Economy period, however, things began to change; all the income from farming labour, including non-farm work, went to the Production Teams, which then distributed it to the collective. While at the beginning non-farm work in factories and cities was not much better paid than farming, these new opportunities demonstrated how much more could be earned from non-farm work, and what kind of lifestyle could be achieved away from farming. Thus, more people wanted to move away from farming [9]. After the Open and Reform Policy, the opportunity cost of rural labour increased dramatically.

"[... B By the end of Collective economy, there were small factories such as brick factory in the village and mechanic factory in the town. At first, the head of the production brigade [Production Teams] designated the workers. The wage per day at the beginning was also low, ranging from 0.08 yuan to 1.3 yuan. You had to hand in part of the salaries for redistribution, because working in the factory certainly much better paid than farming in the village. [ ... ] At 1981, the wage increased to 2-3 Yuan per day, while it was 1 yuan at the most for farming. [ ... ] At 1989-1990, the wage had increased to 30 yuan per day; most of the young farmers were working outside. Even though the rice output peaked at $555 \mathrm{~kg} \mathrm{per} \mathrm{mu,} \mathrm{the} \mathrm{net} \mathrm{income} \mathrm{(of} \mathrm{farming)} \mathrm{was} \mathrm{almost} \mathrm{nothing} \mathrm{if} \mathrm{labour} \mathrm{cost} \mathrm{was}$ included. Farming became part-time job for most of the household. [ ... ] At 2000, the wage was about 50-60 Yuan per day. Now it is 100-200 Yuan per day. Even for those old farmers working for the grass farm in the village, it is about 60 yuan per day." (Male, 50)

While the benefits of agriculture outputs stagnated, the rapid urbanization and industrialization of the region in recent years led to a rapid increase of off-farming opportunities:

"We stopped farming and rented our land to the Grass Company several years ago. Now few villagers continue farming [ ... ] Almost all the young are working outside the village, and impossible to return to farming." (Male, 62)

"Even though farming nowadays is much easier than before, few local people would continue, because it is regarded as hard work. [ ... ] Local people are sensitive to hard work now, so we all gave it up." (Male, 66)

In recent years, the hollowing out of young farmers in search of jobs in the cities has been coupled with the aging of the farming population, and the fact that, despite missing their previous community-based lifestyles, many elderly farmers welcome these changes "because life is now much easier than it once was" [9].

To summarize, the practice of using Lan River Mud was the main source of fertilizer for farmers in the South Yangtze River Delta during the Pre-Liberation and Collective Economy periods. This practice was culturally embedded, involving knowledge of local ecosystems and cycles, with the periodic dredging also contributing to the maintenance of rivers and canals in the delta region for a diverse social and economic uses. In addition, the environmental impact analysis above shows that the practice was a key factor for reducing the environmental impact of farming by reducing the risks of eutrophication in rivers and lakes. However, the use of Lan River Mud was an intensive, physically demanding, dirty and odorous practice. The changes in technology and industrialization during the Late Collective Economy and after the Open and Reform periods led to the welcomed replacement of this practice with more convenient and nitrogen-rich chemical fertilizers. Yet this change in fertilizer use led to large increases in negative impacts on the local water environment, e.g., increased levels of eutrophication. At the same time, the abundance of opportunities in the cities and other industry sectors, coupled with unfavourable conditions of farming labour and the lack of agricultural externalities, led to a dramatic hollowing out of the young farmers from the countryside, resulting in a drastic reduction of available labour force in agriculture and thus even more demand for intensive farming practices.

In light of this, the authors argue that the use of Lan River Mud as a locally available fertilizer could contribute to the development of farming practices with less harmful impacts on the water 
environment due to its demonstrated potential for reducing the risk of eutrophication. However, its successful reintroduction requires careful consideration of the current context of farming. Thus, we now turn to examine existing difficulties and social and environmental criteria for the reinstatement of the traditional farming practice of Lan River Mud, and reduced chemical fertiliser use, or equivalent.

\subsection{Existing Difficulties and Key Criteria for the Reinstatement of Traditional Farming Practices, i.e., Lan River Mud}

In recent years, the development of Shanghai as a major global city has brought increasing attention to the role and condition of peri-urban areas, especially in terms of delivering environmental services such as clean water, as well as being a source of safe agricultural produce. In addition, the emergence of a growing and "health-conscious" middle class has led to increasing interest in more environmentally sustainable farming practices [21,25]. These drivers have led to the search for alternative farming methods and practices expected to have less negative impacts on the environment and human health. In this context, the reinstatement of traditional farming practices, such as the Lan River Mud, acquires particular relevance.

Local governments have announced ambitious programmes to restore the traditional agriculture and lifestyles of Jiangnan water town; for example, the cities of Ningbo and Shaoxing in Zhejiang Province have announced a long term plans for restoring their watertown lifestyle and forcing the update of the cities' industries [68,69]. However, in the process, the importance of Lan River Mud as a potentially beneficial farming practice has been overlooked. As seen from the evidence reported in the previous section, Lan River Mud, as a labour intensive, odorous and dirty farming practice, was not an optimal choice for reintegration by farmers who have completely abandoned this practice, and in the context of a decreasing and aging population in the area. The latter is particularly worrying because the elderly farmers are the ones who possess the local knowledge and expertise to do the job and transmit it to future generations of incoming farmers [9].

Thus the restoration of local farming practices, such as the Lan River Mud, requires careful consideration of the context and conditions necessary for this to happen successfully. Table 7 below depicts some of the required criteria, as identified from the oral histories data, which are necessary for the restoration of traditional farming practices.

First, there is the need for less labour intensive and physically demanding jobs through the modernization of the agricultural sector in general. Within the context of rapid urbanization and increasing scarcity of rural labour, the alternative farming should be no more laborious than other jobs, as farmers are driven by the cost benefit of their labour with respect to a bundle of opportunities in the market. Major investments to modernize infrastructure and machinery could help this issue by improving farmers' working conditions as well as the environmental impact of agriculture, especially in small-scale farming.

Second, less dirty and odorous farming practices. The farmers in our study expressed a clear dislike of dirty, odorous and unpleasant farming practices, such as the dredging of river mud, human and animal faeces. This issue calls for policies and strategies that combine better-paid jobs with better working and living conditions, and less dirty and unpleasant farming techniques. If the option of chemical fertilisers is to be discouraged, then pathways for alternatives need to be carefully developed.

Third, it is necessary to develop strategies to increase the financial returns of farming. Financial returns are important to attract farmers and encourage them to reinstate and maintain environmentally beneficial farming practices. One way of exploring this is the integration of agriculture with other industry sectors in order to allow the development of agricultural services, such as ecological services (eco-tourism industry), historical and cultural service (educational), and landscape and beauty service (environmental conservation). 
Table 7. Criteria for the reinstatement of traditional farming practices in the South Yangtze River Delta Region, as obtained in the oral histories.

\begin{tabular}{|c|c|}
\hline Criteria & Possible Operationalisations \\
\hline $\begin{array}{l}\text { 1. Less labour intensive and } \\
\text { physically demanding jobs }\end{array}$ & $\begin{array}{l}\text { (i) Modernization of agricultural sector } \\
\text { - } \quad \text { Investment in infrastructure and machinery; } \\
\text { - } \quad \text { Technological research and development. }\end{array}$ \\
\hline $\begin{array}{l}\text { 2. Less dirty and odorous } \\
\text { farming practices }\end{array}$ & $\begin{array}{l}\text { (ii) Technological innovation reintegrating traditional practices } \\
\text { - Investing in technology and innovative methods and } \\
\text { techniques for composting and using of organic } \\
\text { fertilizers, e.g., mechanisation of traditional farming } \\
\text { techniques with positive environmental impacts. }\end{array}$ \\
\hline $\begin{array}{l}\text { 3. Strategies to increase the financial } \\
\text { returns of farming }\end{array}$ & $\begin{array}{l}\text { (iii) Socio-economic revitalization } \\
\text { - Integration of agriculture with other industry sectors, } \\
\text { e.g., manufacturing, tourism, education. }\end{array}$ \\
\hline $\begin{array}{l}\text { 4. Elevation of the status of farming } \\
\text { as an honourable occupation } \\
\text { instead of a social identity }\end{array}$ & $\begin{array}{l}\text { (iv) De-stigmatization of agriculture } \\
\text { - Improvement of labour conditions and farming lifestyle } \\
\text { leading to the, i.e., better pay to match shadow price of } \\
\text { urban labour opportunities; } \\
\text { Increase and diversification of agricultural externalities, } \\
\text { e.g., educational farm visits, recreational activities, } \\
\text { restoration and conservation of traditional landscapes; } \\
\text { - Valuing and promoting traditional, practical farming } \\
\text { knowledge between "old" and "new" farmers. }\end{array}$ \\
\hline
\end{tabular}

Fourth, the elevation of the status of farming as an honourable occupation instead of a social identity. Our oral histories reveal an underlying stigma of farmers as a lower quality of persons, and of agriculture as an unworthy occupation. The latter becomes apparent in the reluctance of elderly farmers to encourage and pass on old ways, cultural traditions and practical knowledge to future generations. This issue calls for a re-defining or re-alignment of farming beyond mere modernisation, for example, with an integration with other industries and sectors, to provide spaces and opportunities for the multi-functionality and de-stigmatization of agriculture, e.g., maximization of labour force (part-time farming), and agricultural externalities (ecotourism, and education).

\section{Discussion}

\subsection{A Comparison with a Contemporary Japanese Case}

Having elicited from oral histories enough information to identify key changes in agricultural practices leading to environmental harm, and the key broad social criteria to be addressed in any future plans, we turn our attention in this section to specific lessons that can be learned from policies implemented in Japan. We think it is useful to consider potential scenarios or existing similar cases elsewhere where the reintroduction of traditional farming practices has proven successful, and to evaluate whether the same or similar strategies could work for the restoration of or substitution for the Lan River Mud farming technique in the Yangtze River Delta region.

Recent efforts to revive traditional farming and landscapes in the satoyama, upland, rural areas of Japan offer a directly relevant example for our study. First, because efforts and developments happening now in Japan meet all the required criteria for the reinstatement of traditional farming practices and their reproduction in China seems to be feasible. Second, because they also provide successful, on-going strategies to reconnect people from younger generations to the land, and revalue and promote traditional, local farming knowledge and lifestyles, thus helping de-stigmatize the agriculture industry. 
Japan's push for modernisation following the end of WWII brought dramatic structural and socio-economic changes; agricultural lands were reorganised to meet the increasing demands in production and accommodate new machinery, roads were widened and irrigation systems consolidated, terraced paddies were flattened, and electricity and domestic appliances in villagers' households made more accessible. By the 1970s, Japanese agriculture was "the most mechanized and chemical-dependent in the world" [70], cited in ([14], p. 394).

Initially, modernisation was welcomed in rural areas as mechanisation helped improve the lifestyles and working conditions of farmers. However, the increase in scale and machinery, and the intensive use of chemical fertilizers actually resulted in a nationwide decline of agricultural productivity and increase in imported foods [71], stemming largely from a decreasing and aging farming population and the failure to integrate the liberalisation of the economy with agricultural policies [14]. Over the last 30 years, there have been increasing concerns about the deterioration of its satoyama regions due to the rapid industrialisation and urbanisation following WWII, as well as the under-management and depopulation of farming lands caused by rural-urban migration and aging population [72]. Satoyama regions are very important to Japan as they represent about $43 \%$ of Japan's cultivated lands and contribute to $39 \%$ of its national agricultural production ([14], p. 393).

What then can Japan's strategies for the restoration of its upland rural areas and traditional farming practices tell us? How do these efforts meet our identified criteria for restoration of traditional farming? Are they applicable to the Yangtze River Delta region?

(1) Less labour intensive and physically demanding jobs

In terms of our first criteria for restoration, two major developments leading to changes in agricultural practices seem worth highlighting here. First is the development of Kyusei nature farming which was first envisioned by Mokichi Okada in 1935, although it was not until the early 1980s that it acquired greater attention for agricultural production with the use of the effective microorganisms (EM) technology developed by Dr Teruo Higa [73].

EM technology involves a living culture that improves soil and water quality and reduces growth of harmful bacteria, thus increasing and crop yield-among other reported benefits. While the microorganisms' survival, growth and reproduction depend on specific geographical conditions and soil environments, its adoption and application along with the principles of Kyusei nature farming in other countries is as much a matter of technology research as of political will. EM technology, however, has seen many applications and been used in over 100 countries for farming with reduced chemical fertilizer input (including major grain crops, cotton, or tobacco), environmental management in terms of animal enhanced productivity and better health resulting from EM fermented livestock feed, treatment of wastewater, as well as in non-food crops, at both experimentation and production scales [74]. The potential for its implementation and the philosophy of approach behind EM techniques could be relevant: it advocates for a production system with minimal disruption to the local ecosystem, while at the same time aims to achieve high productivity of agricultural products without chemical fertilizers and with less labour physical input.

(2) Less dirty and odorous farming practices

The second development is Japan's government consistent efforts to promote the multi-functionality of its rural areas, which resulted in farmers spending less of their time in heavy farm work. Indeed, there has also been extensive government investment in technology and machinery such as small scale composting plants for all the villages, including transportation machines to every small piece of farmland. Technologies have been applied to eliminate odorous works as well as improve the efficiency of organic fertilizers, of which the application of EM technology is an example. 
(3) Strategies to increase the financial returns of farming

In its 2014 annual report, the Japanese Ministry of Agriculture, Forestry and Fisheries (MAFF) outlines detailed measures to increase the multi-functionality payments of agriculture through the promotion of local community functions (landscape biodiversity preservation, the development of renewable energies as well as responses to climate change and environmental disaster prevention and resilience) [71]. The report also gives indications of improved rural-urban exchanges and integration of agriculture with other industry sectors (reforms in the production-supply chain to encourage more sustainable farming, the establishment of farmland banks, eco-tourism and education, and institutional support for women's markets). The economic diversification of rural and natural areas, and the broad support from both the government and academic sectors, as well as that of an engaged general population, has contributed dramatically to improve the working conditions of farming jobs and reduce the de-stigmatization of agriculture.

Japanese agricultural modernisation developed first and more rapidly in the flatland rural areas in the 1950s and 1960s, and later in the satoyama regions during the 1980s [14]. However, unlike in China, "the rationalization and modernization of agriculture did not stamp out some of the core pieces of the hyakusho way of life: traditional hamlet social structure, subsistence-oriented livelihood strategy among farming households, and many traditional agricultural practices, especially in upland areas where the topography limited the extent of infrastructural change" ([14], p. 395). This led in turn to the coexistence of, on the one hand, the traditional Japanese hamlet (village) consisting of multiple interdependent households as the basic operational units for farming and, on the other hand, the socio-economic and structural changes brought forth by modernisation. In order to balance hamlet and household obligations, farmers in the upland areas have resorted to "pluriactivity" strategies (part-time farming combined with salaried jobs off-farm). "Livelihood strategies such as pluriactivity reinforce the idea of farming as a familial activity and the values of household participation in agriculture, as a form of social linkage with the hamlet, and self-sufficiency at the household and hamlet levels." ([14], p. 396).

The MAFF later initiated efforts to revitalise rural areas through a policy programme called "sixth industry". The "sixth industry" creates new added-value by effectively integrating the production, processing and distribution activities of the agriculture, manufacturing and service industries [14]. This development is also relevant to the Yangtze River Delta region as its operationalisation is based on the integration of different industry sectors and thus paves the way to increase the financial returns and added value of farming.

Some of the initiatives and solutions to restore and preserve the satoyama areas and traditional farming practices include: inviting people to rent small plots to cultivate rice and vegetables, emphasizing the value of ecosystem services, such as the model "refuelling satoyama woodlands" developed by a research group in Tokyo University which highlights the use of coppiced woodlands as a carbon neutral and large-scale energy. Wood biomass energy used at an industrial scale can also create new employment opportunities for local people. Other alternatives have focused on the integration of rural areas with cities, such as educational activities and school visits as well as the promotion of the medical importance of natural areas through active recreation, or forest therapy activities. Another important initiative is that of the mura-okoshi (village restoration) movement where citizens organise associations for voluntary woodland restoration (clearing, coppicing) ([72], p. 572). There is also an abundance of economic activities besides farming, such as rural tourism, children education programmes, and nature areas visits and activities. For example, the farms in Tokyo that engaged in organic farming covered about $42 \%$, and about $1.6 \%$ of farms engaged in rural tourism.

(4) Elevation of the status of farming as an honourable occupation

There has also been in Japan a growing interest in the conservation and restoration of satoyama landscapes and traditional agricultural practices, as evidenced by organic agricultural and nature farming movements started in the 1970s. These movements would later lead the MAFF to establish the 
Office of Organic Agriculture in 1989 [73]. Another influential development has been the Satoyama and Satoumi Assessment (JSSA), an international project initiated in 2007 between the UN University Institution of Advanced Studies and the Japanese Ministry of Environment, and which would later be renamed as SEPLS; socio-ecological production landscapes and seascapes. This widened interest of Japanese people stems not only from the support of the government but also from the recognition by scientist, ecologists and engineers of the ecological benefits as well as cultural values of the upland rural areas [72]. Many of these interests have been spurred by influential literary works and monographic publications like Fukugō Osen (Complex Pollution) [75], Satoyama and its conservation [76], and Satoyama, The Traditional Rural Landscape of Japan [77].

However, this combination of modernization with traditional farming and social organisations, has failed to attract enough younger generations of successive family farmers, leading to a contraction of the farming sector and subsequently to a deterioration of the hamlet society, especially in the upland areas [14]. On the one hand, the increased awareness of the precariousness of Japanese agriculture, the idea of "connecting with nature" and living a simple, sustainable, self-sufficient lifestyle, has driven many urban dwellers to scape to the countryside and engage in farming, especially organic farming. This phenomenon is particular for the prefecture of Nagano. These new organic farmers are supporting each other through ad hoc networks of local and regional farmers' union cooperatives for financial support, extension services, and distribution of produce. Another form of support is through national and prefectural research associations that hold meetings, network members, and publish newsletters, as well as provide advice on farming practices and management, as well as about unwritten rules of life in rural hamlets.

On the other hand, however, these "new" organic farmers are often left alone and lack a more structured support. Furthermore, the resettlement of Japanese urbanities to rural areas is just but a part of the process to contribute to the elevation of the status of farming as an honourable occupation. "New", incoming farmers require the necessary local knowledge to get started and improve their agricultural skills [14]. The knowledge is there but failure to recognize local farmers' knowledge and practices, the lack of promotion mechanisms to encourage dialogue and exchange between incoming and local farmers, and the pre-existent stigma of inferiority and anti-sociability amongst other local farmers, makes it difficult $[9,14]$.

\subsection{South Yangtze River Delta Reality and Suggestions for a Potential Future Scenario}

Having outlined lessons from Japan in the section above, in this section we consider some sporadic developments in the Yangtze River Delta region which show promise as elements for reintroducing or adapting traditional farming practices for a future scenario, and then suggest how they might be further linked and developed to be more effective on a larger scale.

(1) Less labour intensive and physically demanding jobs

Plans for the development and operation of a small, easy to operate river mud dredging pump were outlined in a paper published at the University of Zhejiang in 1990 [78]. The paper described the design of a sucking device with two different pumps to filter out the water from the river mud. The prototype was small and it attached to any boat. It was easy to operate by only one person and ran on a diesel engine, thus reducing the cost and effort of dredging, drying and transporting the Lan River Mud from the water source to the cultivating fields. Unfortunately, however, during the course of our field research none of the interviewed farmers seemed to know about the existence of this equipment. Such technology, or similar, could be crucial to solve the intensive and time-consuming labour involved in the practice of Lan River Mud. However, more research is required to reduce the amounts of water that is extracted together with the river mud as otherwise the time spent for drying makes the whole process ineffective. Furthermore, should such technologies be put into use, careful calculations would need to be made to identify an ecologically sustainable rate of extraction. Dredging also requires deep knowledge of the local water ecosystems to establish the appropriate 
scope and depth of dredging activities [79], and thus leads to implications for maximum nutrient availability using Lan River Mud as a fertilizer.

There have also been reported actions to integrate the agriculture and aquaculture industries. In the coastal city of Yueqin, Zhejiang province, the coordination of efforts has proven beneficial for both farming and water treatment practices, reducing silting and restoring biodiversity, unblocking of canals, and improving the efficiency of the dredging [80]. However, these are very much localized efforts, not spread out to the rest of the South Yangtze River Delta. The maximization of Lan River Mud's extraction and its properties depends on a broader integration of the agriculture and water industries through more government efforts in terms of financial incentives for technological innovation and appropriate machinery.

\section{(2) Less dirty and odorous farming practices}

In the Cenbu village, near the Tianshanzhuang watertown, a group of approximately six farms, mainly new incoming farmers, have been farming "organically" and using alternative, less dirty and odorous fertilizers such as the composting of mushroom sticks-a residue of mushroom production, produced by aerobic fermentation. In Chongming Island, we have also observed organic farming in 10 farms, where they also use biogas slurry from a large biogas plant, to irrigate rice and vegetables.

Other examples to reduce dirty and odorous farming practices in China are the application of EM technology as fertilizer for the production of cotton and tobacco [74], or its use to reduce odours in waste. In Guangzhou, a group of researchers applied EM to old refuse collection stations that built since 1990 by the Guangzhou government. Residents were complaining as these stations were close to residential areas and they were producing bad smells. After a period of 21 days not only did the EM reduce the bad smells from the refuse stations, but it also contributed to the cleaning up of sewage as some of the EM ran down into the drainage system [81].

(3) Strategies to increase the financial returns of farming, and 4. Elevation of the status of farming as an honourable occupation

The Chinese reality is complex. The case of the Cenbu village is relevant as they have developed practices that mirror, although weakly, aspects of multi-functionality taking place in Japan. For example, there are educational farm visits carried out, ecotourism and recreational activities. In addition, these farms offer companies and institutions a special service to host employees for training in farming. All of these activities are promoted through WeChat, one of China's most widely used social media platforms (Liu Pingyang, personal observation).

While these initiatives reveal that there is some demand for organic produce, the development of such types of sustainable farming practices is limited only to new farmers and on a small scale. Farmers of Cenbu village and Chongming Island are hindered as they have to sell their produce at a price $5-10$ times the norm. In addition, the lack of facilitating infrastructure and clear government support or incentives make the reproduction or extension of these initiatives very difficult. At the time of writing, there are over 30 other small organic farms reported in the suburbs of Shanghai, yet they do not yet have clear legal spaces to advertise or trade, and there are no clear mechanisms to improve this situation in a country with a partially commercial and partially centrally planned mode of operation. Furthermore, many organic farmers opt not to register as organic producers due to the high costs of the certification, something also reported in Japan [14], and also because they suffer the ostracism from other farmers [9].

Since the Open and Reform period, market reforms and the opening of China to the rest of the world have encouraged the development of more sustainable farming practices. However, organic farming has only developed at small-scales, limited by higher price premiums, added costs (amongst others, organic certification and intensive labour due to low mechanization), with a limited output in the short-term, which make it cost ineffective [29,82]. Individual farmers are "simply unable to deal with the risks, difficulties and dangers of going organic when his/her neighbours continue to 
use conventional methods" [11]. Thus, the Chinese agricultural sector faces serious structural obstacles that must first be overcome if it is to become more sustainable. These obstacles include the increasing small-scale nature, and consequent fragmentation, of farming, the insufficient mechanization of the sector, and financial insecurity derived from inadequate access to capital and unbalanced market factors [29].

The isolated examples given above show both possibilities and limitations to a move towards more environmentally sustainable farming in the Yangtze River Delta region that draw on specific traditional practices that are now known to have significant potential for reducing the risk of eutrophication in the water environment: dredging Lan River Mud. It seems possible, with carefully considered portfolios of policies, that farmers could be encouraged to adopt simple mechanisation for reintroducing some aspects of traditional practices, while incorporating new practices such as the use of natural fertilisers (organic, mushroom sticks, and EM) which are less odorous and labour intensive. In effect, dredging alone is known to not be sufficient for reducing eutrophication, and needs to be accompanied with reduced external input of $\mathrm{N}$ and $\mathrm{P}$ into the agricultural production cycle [65]. Such developments would need to be accompanied by further research on specific impacts on the water environment and the implications of these new fertilization methods for crop yield. This will confirm their potential for meeting demands for environmental services with the production of abundant and safe agriculture produce for a city of over 24 million inhabitants where $90 \%$ of green-leaf vegetables are produced for local consumption [21].

\section{Conclusions}

The oral histories of the 31 farmers from Tianshanzhuang village, near Shanghai, have provided detailed information on past farming practices, allowing estimates to be made of the nitrogen and phosphorus burdens on the land from fertilizer use over three historical periods: Pre-Liberation (pre-1949), Collective Economy (1950-1983), and Open and Reform (1980s onwards). The analysis permitted the authors to identify the reduced use of Lan River Mud and increased use of chemical fertilisers as the two main changes in practices, which undermine the health of the water environment. While the role of chemical fertilizer use in enhancing potential for eutrophication in water environments is widely recognised across agricultural contexts [83], the analysis showed that the use of Lan River Mud not only served as a fertilizer, but also contributed to reducing the risk of eutrophication by assimilating and recycling nitrogen and phosphorous in the agricultural production cycle. It is, thus, of particular interest in the context of developing locally suitable agricultural practices that will also minimise negative environmental impacts. The same oral histories revealed four key social barriers to any reintroduction of traditional practices, and which would have to be considered in the development of future scenarios. These barriers are: (1) the need for less labour intensive and physically demanding jobs; (2) less dirty and odorous farming practices; (3) the development of strategies to increase the financial returns of farming; and (4) the elevation of the status of farming to an honourable occupation.

Through a consideration of a series of changes in farming practices in Japan, and of isolated emerging practices in China, the authors have identified technical innovations and economic and social opportunities that would allow the integration of traditional practices, in particular the use of Lan River Mud, in contemporary efforts to develop ecological farming in the Jiangnan region. The authors present a timely and fruitful area for future research, but recognize that more research is needed on sustainable rates of extraction, detailed combinations of fertilization practices that include the use of Lan River Mud, and their respective impacts on yield.

In light of emerging practices in China and examples from Japan, the authors identify a clear opportunity, and the necessity, to develop a coordinated vision in order to plan changes in practices. This would require a shift in perceptions of farming, the willingness to engage in cross-generational learning, and the cooperation of several stakeholders with various related government departments in China but could then lead to a portfolio of policy changes and thus farming practices which could be reproduced elsewhere in China. We envisage this future to include new methods and uses of 
Lan River Mud; the integration of leisure and tourism industries with agriculture; the production of organic produce and well-planned internet-linked sales, delivery and coordination mechanism; and the active on-going involvement and working alongside of appropriate government departments including the Environmental Protection Bureau, water sanitation, tourism, leisure and culture.

Acknowledgments: Pingyang Liu was funded by the National Natural Science Foundation of China (41201589), and Marie K. Harder by the China National Thousand Talents program. We would like to thank the anonymous reviewers for their insightful comments and constructive criticism on earlier drafts of this article.

Author Contributions: Pingyang Liu and Marie K. Harder conceived and designed the research; Peiying Song assisted Pingyang Liu with the oral history interviews and initial analysis of the data; Juan M. Moreno led on the writing of the paper and developing the links with other literature conversations; Elona Hoover and Juan M. Moreno contributed in the methodological approach; and Pingyang Liu, Elona Hoover, Juan M. Moreno and Marie K. Harder contributed to the material analysis and the improvement of the paper.

Conflicts of Interest: The authors declare no conflict of interest.

\section{Abbreviations}

The following abbreviations are used in this manuscript:

$\begin{array}{ll}\text { EM } & \text { Effective microorganism technology } \\ \text { HRS } & \text { Household Responsibility System } \\ \text { LCA } & \text { Life Cycle Assessment } \\ \text { N } & \text { Nitrogen } \\ \text { MAFF } & \text { Japanese Ministry of Agriculture, Forestry and Forestry and Fisheries } \\ \text { O.P. } & \text { Open and Reform period } \\ \text { P } & \text { Phosphate } \\ \text { WWII } & \text { World War II }\end{array}$

\section{References}

1. Li, B. Agricultural Development in Jiangnan, 1620-1850; St. Martin's Press: New York, NY, USA, 1998.

2. Shen, S.; Wilkes, A.; Qian, J.; Yin, L.; Ren, J.; Zhang, F. Agrobiodiversity and Biocultural Heritage in the Dulong Valley, China: Impacts of and Responses to the Sloping Land Conversion Program. Mt. Res. Dev. 2010, 30, 205-211. [CrossRef]

3. Liu, Y.; Duan, M.; Yu, Z. Agricultural landscapes and biodiversity in China. Agric. Ecosyst. Environ. 2013, 166, 46-54. [CrossRef]

4. Ye, X.J.; Wang, Z.Q.; Li, Q.S. The ecological agriculture movement in modern China. Agric. Ecosyst. Environ. 2002, 92, 261-281. [CrossRef]

5. Huang, C.C.; Tsai, M.H.; Lin, W.T.; Ho, Y.F.; Tan, C.H. Multifunctionality of paddy fields in Taiwan. Paddy Water Environ. 2006, 4, 199-204. [CrossRef]

6. Lin, X.-L.; Zhou, Y.-H. An Analysis on the Eco-environment Effect of Circular Agriculture Mode of Planting-Culture in the Paddyfield. China Popul. Resour. Environ. 2012, 3. Avaliable online: http://en.cnki.com.cn/Article_en/CJFDTOTAL-ZGRZ201203009.htm (accessed on 2 February 2016). (In Chinese)

7. Mao, Z.; Gu, X.; Lu, X.; Zeng, Q.; Gu, X.; Li, X. Ecological effects of dredging on aquatic ecosystem in the different regions of eastern Lake Taihu. J. Lake Sci. 2014, 26, 385-392.

8. Ji, X.; Zheng, S.; Liu, Q. Effect of Organic Manure Application on Runoff Phosphorus Loss from Rice-Rice Field in the Middle Reach of the Yangtze River. J. Hunan Agric. Univ. 2006, 32, 283-287.

9. Liu, P.; Ravenscroft, N.; Harder, M.K.; Dai, X. The knowledge cultures of changing farming practices in a water town of the Southern Yangtze Valley, China. Agric. Hum. Values 2015. [CrossRef]

10. Fei, X. Peasant Life in China: A Field Study of Country Life in the Yangtze Valley; Routledge and Kegan Paul: London, UK, 1939.

11. Sanders, R. Organic Agriculture in China: Do property rights matter? J. Contemp. China 2006, 15, 113-132. [CrossRef]

12. Chen, X. Review of China's agricultural and rural development: Policy changes and current issues. China Agric. Econ. Rev. 2009, 1, 121-135. [CrossRef] 
13. Feng, K.; Zhang, J.; Huang, Y.W. Review of China's agricultural integration development: 1978-2008. China Agric. Econ. Rev. 2009, 1, 459-477. [CrossRef]

14. McGreevy, S.R. Lost in translation: incomer organic farmers, local knowledge, and the revitalization of upland Japanese hamlets. Agric. Hum. Values 2012, 29, 393-412. [CrossRef]

15. Li, D.; Liu, M.; Deng, G. Willingness and determinants of farmers' adoption of new rice varieties. China Agric. Econ. Rev. 2010, 2, 456-471. [CrossRef]

16. Van der Ploeg, J.D.; Ye, J.; Pan, L. Peasants, time and the land: The social organization of farming in China. J. Rural Stud. 2014, 36, 172-181.

17. Xiong, W.; Lin, E.; Jiang, J.; Li, Y.; Xu, Y. An integrated analysis of impact factors in determining China's future grain production. Acta Geogr. Sinica 2010, 65, 397-406. (In Chinese)

18. Zhang, H.; Shan, B. Historical records of heavy metal accumulation in sediments and the relationship with agricultural intensification in the Yangtze-Huaihe region, China. Sci. Total Environ. 2008, 399, 113-120. [CrossRef] [PubMed]

19. NBSC. National Census of Pollution Sources Report; NBS Bulletin; National Bureau of Statistics of China: Beijing, China, 2010. (In Chinese)

20. Qian, X.; Shen, G.; Guo, C.; Gu, H.; Zhu, Y.; Wang, Z. Source apportionment and spatial heterogeneity of agricultural non-point source pollution based on water environmental function zoning. Trans. Chin. Soc. Agric. Eng. 2011, 27, 103-108.

21. Zhou, Y.; Ao, Y. The status quo and characteristics of external vegetable consumption in Shanghai. Acta Agric. Shanghai 2016, 32, 95-99. (In Chinese)

22. Shi, Y.; Cheng, C.; Lei, P.; Wen, T.; Merrifield, C. Safe food, green food, good food: Chinese Community Supported Agriculture and the rising middle class. Int. J. Agric. Sustain. 2011, 9, 551-558. [CrossRef]

23. Muldavin, J.S. Impact of reform on environmental sustainability in rural China. J. Contemp. Asia 1996, 26, 289-321. [CrossRef]

24. Paull, J. China's organic revolution. In Marketing of Organic Products: Global Experiences; The Icfai University Press: Hyderabad, India, 2008; pp. 260-275.

25. Sirieix, L.; Kledal, P.R.; Sulitang, T. Organic food consumers' trade-offs between local or imported, conventional or organic products: A qualitative study in Shanghai: Local and imported organic product. Int. J. Consum. Stud. 2011, 35, 670-678. [CrossRef]

26. Guang, L.; Zheng, L. Migration as the second-best option: Local power and off-farm employment. China $Q$. 2005, 181, 22-45. [CrossRef]

27. Ding, S.; Meriluoto, L.; Reed, W.R.; Tao, D.; Wu, H. The impact of agricultural technology adoption on income inequality in rural China: Evidence from southern Yunnan province. China Econ. Rev. 2011, 22, 344-356. [CrossRef]

28. Chen, J.; Lu, J. Effects of Land Use, Topography and socio-economic factors on river water quality in a mountainous watershed with intensive agricultural production in east China. PLOS ONE 2014, 9, e102714. [CrossRef] [PubMed]

29. Sanders, R. A Market Road to Sustainable Agriculture? Ecological Agriculture, Green Food and Organic Agriculture in China. Dev. Chang. 2006, 37, 201-226. [CrossRef]

30. Ye, J. Land Transfer and the Pursuit of Agricultural Modernization in China. J. Agrar. Chang. 2015, 15, 314-337. [CrossRef]

31. Chen, F.; Davis, J. Land reform in rural China since the mid 1980s. Land Reform Land Settl. Coop. 1998, 6, 123-137.

32. Yang, H.; Li, X. Cultivated land and food supply in China. Land Use Policy 2000, 17, 73-88. [CrossRef]

33. Lv, Y.; Gu, S.-Z.; Guo, D.-M. Valuing environmental externalities from rice-wheat farming in the lower reaches of the Yangtze River. Ecol. Econ. 2010, 69, 1436-1442. [CrossRef]

34. Li, Y.; Liu, Y.; Long, H.; Cui, W. Community-based rural residential land consolidation and allocation can help to revitalize hollowed villages in traditional agricultural areas of China: Evidence from Dancheng County, Henan Province. Land Use Policy 2014, 39, 188-198. [CrossRef]

35. Haynes, K. Other lives in accounting: Critical reflections on oral history methodology in action. Crit. Perspect. Account. 2010, 21, 221-231. [CrossRef]

36. Walker, M. Narrative themes in oral histories of farming folk. Agric. Hist. 2000, 74, 340-351. 
37. Riley, M.; Harvey, D. Talking geography: On oral history and the practice of geography. Soc. Cult. Geogr. 2007, 8, 345-351. [CrossRef]

38. Tagseth, M. Oral history and the development of indigenous irrigation. Methods and examples from Kilimanjaro, Tanzania. Nor. Geogr. Tidsskr. Nor. J. Geogr. 2008, 62, 9-22. [CrossRef]

39. Riley, M. Emplacing the Research Encounter: Exploring Farm Life Histories. Qual. Inq. 2010, 16, 651-662. [CrossRef]

40. Colburn, L.L.; Clay, P.M. The Role of Oral Histories in the Conduct of Fisheries Social Impact Assessments in Northeast US. J. Ecol. Anthropol. 2011, 15, 74-80. [CrossRef]

41. Wan, G.; Zhou, Z. Income Inequality in Rural China: Regression-based Decomposition Using Household Data. Rev. Dev. Econ. 2005, 9, 107-120. [CrossRef]

42. I Canals, L.M.; Burnip, G.; Cowell, S. Evaluation of the environmental impacts of apple production using life cycle assessment (LCA): Case study in New Zealand. Agric. Ecosyst. Environ. 2006, 114, 226-238. [CrossRef]

43. Cowell, S.J.; Clift, R. Impact assessment for LCAs involving agricultural production. Int. J. Life Cycle Assess. 1997, 2, 99-103. [CrossRef]

44. De Boer, I.J. Environmental impact assessment of conventional and organic milk production. Livest. Prod. Sci. 2003, 80, 69-77. [CrossRef]

45. Brentrup, F.; Küsters, J.; Kuhlmann, H.; Lammel, J. Environmental impact assessment of agricultural production systems using the life cycle assessment methodology: I. Theoretical concept of a LCA method tailored to crop production. Eur. J. Agron. 2004, 20, 247-264. [CrossRef]

46. Zhang, L.; Xia, M.; Zhang, L.; Wang, C.; Lu, J. Eutrophication status and control strategy of Taihu Lake. Front. Environ. Sci. Eng. China 2008, 2, 280-290. [CrossRef]

47. Ministry of Environmental Protection of the People's Republic of China. On the Reduction of Discharge Fee of Animal Raising Related Issues, 2004. Avalible online: http://www.mep.gov.cn/gkml/zj/wj/200910/ t20091022_172271.htm (accessed on 20 June 2016). (In Chinese)

48. Tao, L.A.I.; Cha-gou, L.I.; Huang, Q.H.; Wu, J.-H. Study on Sources of Organic Nitrogen in Chinese Milk Vetch on Red Paddy Soil. Acta Agric. Jiangxi 2002, 2, 2. (In Chinese)

49. Zhou, J. Fertilizer. J. Zhejiang Agric. Sci. 1962, 11, 528-532. (In Chinese)

50. Tian, Y.-H.; Yin, B.; Yang, L.-Z.; Yin, S.-X.; Zhu, Z.-L. Nitrogen runoff and leaching losses during rice-wheat rotations in taihu lake region, china. Pedosphere 2007, 17, 445-456. [CrossRef]

51. Howarth, R.W.; Boyer, E.W.; Pabich, W.J.; Galloway, J.N. Nitrogen use in the United States from 1961-2000 and potential future trends. Ambio 2002, 31, 88-96. [CrossRef] [PubMed]

52. Howarth, R.; Swaney, D.; Billen, G.; Garnier, J.; Hong, B.; Humborg, C.; Marino, R. Nitrogen fluxes from the landscape are controlled by net anthropogenic nitrogen inputs and by climate. Front. Ecol. Environ. 2012, 10, 37-43. [CrossRef]

53. Juan, Y.; Liangjun, F.; Juncang, T.; Yanfang, W.; Bingfang, H.; Xueke, Z.; Shaoping, M. Research advance of nitrogen fertilizer losses from paddy field. Trans. Chin. Soc. Agric. Eng. 2005, 6, 42.

54. Dai, X. Fudan University, Shanghai, China. Personal communication, 2012.

55. Zhao, X.; Zhou, Y.; Min, J.; Wang, S.; Shi, W.; Xing, G. Nitrogen runoff dominates water nitrogen pollution from rice-wheat rotation in the Taihu Lake region of China. Agric. Ecosyst. Environ. 2012, 156, 1-11. [CrossRef]

56. Pan, G.; Zhou, P.; Li, Z.; Smith, P.; Li, L.; Qiu, D.; Zhang, X.; Xu, X.; Shen, S.; Chen, X. Combined inorganic/organic fertilization enhances $\mathrm{N}$ efficiency and increases rice productivity through organic carbon accumulation in a rice paddy from the Tai Lake region, China. Agric. Ecosyst. Environ. 2009, 131, 274-280. [CrossRef]

57. Geng, P.; Cao, G.; Ding, F. Study on Fertilization Model of Nitrogen, Phosphorus and Potassium for High Yield of Rice. J. Anhui Agric. Sci. 2008, 36, 11852-11854. (In Chinese)

58. Liu, S.F.; Li, Y.X.; Zhang, X.L.; Feng, C.H.; Lu, X.F.; Yang, M.; Li, W.; Zhu, T.Q.; Huang, Z.C. The excretion features of manure-borne steroid hormones and their potential risk in the municipalities of China. Acta Sci. Circumst. 2013, 33, 2314-2323. (In Chinese)

59. Sleeswijk, A.W.; van Oers, L.F.; Guinée, J.B.; Struijs, J.; Huijbregts, M.A. Normalisation in product life cycle assessment: An LCA of the global and European economic systems in the year 2000. Sci. Total Environ. 2008, 390, 227-240. [CrossRef] 
60. Wang, M.X.; Bao, Y.H.; Wu, W.L.; Liu, W.N. Life Cycle Environmental Impact Assessment of Winter Wheat in North China Plain. J. Agro-Environ. Sci. 2006, 25, 1127-1132.

61. Murakami, K. Dredging for controlling eutrophication of Lake Kasumigaura, Japan. Lake Reserv. Manag. 1984, 1, 592-598. [CrossRef]

62. He, Q. River mud ditch is good fertilizer. Sichuan Agric. Sci. Technol. 1987, 4, 30. (In Chinese)

63. Fang, B.H. Jiangsu province resources survey and utilization of river mud. Soil Fertil. 1993, 8, 30-32. (In Chinese)

64. Zhang, S.; Zhou, Q.; Xu, D.; Lin, J.; Cheng, S.; Wu, Z. Effects of sediment dredging on water quality and zooplankton community structure in a shallow of eutrophic lake. J. Environ. Sci. 2010, 22, 218-224. [CrossRef]

65. Schindler, D.W. Recent advances in the understanding and management of eutrophication. Limnol. Oceanogr. 2006, 51, 356-363. [CrossRef]

66. Stoate, C.; Báldi, A.; Beja, P.; Boatman, N.D.; Herzon, I.; van Doorn, A.; de Snoo, G.R.; Rakosy, L.; Ramwell, C. Ecological impacts of early 21st century agricultural change in Europe-A review. J. Environ. Manag. 2009, 91, 22-46. [CrossRef] [PubMed]

67. Yang, X.; Fang, S.; Lant, C.L.; Luo, X.; Zheng, Z. Overfertilization in the economically developed and ecologically critical Lake Tai region, China. Hum. Ecol. 2012, 40, 957-964. [CrossRef]

68. Shaoxing Municipal Administration Office. Guideline for the Industrial Update and the Water City Restoration, 2013. Available online: http://www.sx.gov.cn/art/2013/10/29/art_126_431890.html (accessed on 20 January 2016). (In Chinese).

69. Ningbo Municipal Administration Office. New Governance Strategies for Restoration of Yangtze River Delta. 2014. Available online: http://www.cnnb.com.cn/nbzfxwfbh/system/2014/06/05/008079093.shtml (accessed on 20 January 2016). (In Chinese).

70. Teruoka, S. Agriculture in the Modernization of Japan, 1850-2000; Manohar Publishers: New Delhi, India, 2008.

71. MAFF. FY2014 Annual Report on Food, Agriculture and Rural Areas in Japan: Summary; Japanese Ministry of Agriculture, Forestry and Fisheries: Tokyo, Japan, 2014.

72. Berglund, B.E.; Kitagawa, J.; Lagerås, P.; Nakamura, K.; Sasaki, N.; Yasuda, Y. Traditional farming landscapes for sustainable living in Scandinavia and Japan: Global revival through the Satoyama Initiative. Ambio 2014, 43, 559-578. [CrossRef] [PubMed]

73. Arakawa, Y. Kyusei Nature Farming in Japan. In Proceedings of the First International Conference on Kyusei Nature Farming, Khon Kaen, Thailand, 17-21 Octobor 1989.

74. Higa, T. Kyusei Nature Farming and Environmental Management Through Effective MicroorganismsThe Past, Present and Future. In Proceedings of the Seventh International Conference on Kyusei Nature Farming, Christchurch, New Zealand, 15-18 January 2002.

75. Sawako, A. Fukugō Osen; Ushio Shuppansha: Tokyo, Japan, 1977.

76. Tabata, H. Satoyama and Its Conservation; Hoikusha: Osaka, Japan, 1997.

77. Takeuchi, K.; Brown, R.D.; Washitani, I.; Tsunekawa, A.; Yokohari, M. (Eds.) Satoyama: The Traditional Rural Landscape of Japan; Springer Japan: Tokyo, Japan, 2003.

78. Weiya, Z.; Li, J.; Yesi, Q.; Wang, X. Study of a small-size multifunctional sucking vessel for returning the river silt to fields. Acta Agric. Univ. Zhejiangensis 1990, 5, 113-114. (In Chinese)

79. Qin, B. Approaches to Mechanisms and Control of Eutrophication of Shallow Lakes in the Middle and Lower Reaches of the Yangze River. J. Lake Sci. 2002, 14, 193-202. (In Chinese)

80. Wu, P.; Chen, Y.; Wang, Y.; Bai, P. River mud suction and irrigation of "late—cantaloupe" fields: An efficient model and supporting technology. Farm. Cultiv. 2006, 2, 43-44.

81. Lau, K.K. EM Deodoration Treatment in Guangzhou. In Proceedings of the Seventh International Conference on Kyusei Nature Farming, Christchurch, New Zealand, 15-18 January 2002.

82. Kledal, P.R.; Hui, Q.Y.; Egelyng, H.; Xi, Y.; Halberg, N.; Li, X. Organic Food and Farming in China. World Org. Agric. Stat. Emerg. Trends 2007. Avaliable online: http:/ /orgprints.org/11246/ (accessed on 2 February 2016).

83. Withers, P.J.; Neal, C.; Jarvie, H.P.; Doody, D.G. Agriculture and eutrophication: Where do we go from here? Sustainability 2014, 6, 5853-5875. [CrossRef]

(C) 2016 by the authors; licensee MDPI, Basel, Switzerland. This article is an open access article distributed under the terms and conditions of the Creative Commons Attribution (CC-BY) license (http://creativecommons.org/licenses/by/4.0/). 